\title{
Comment
}

\section{BRINGING NEW PARTIES INTO CIVIL ACTIONS IN CALIFORNIA}

The 1957 session of the California Legislature endeavored to revise the provisions of the Code of Civil Procedure with respect to the bringing in of new parties in civil actions but, by amending sections $389,{ }^{1}$ whicls deals with joinder, and $442,{ }^{2}$ concerning cross-complaints, it created many new and perhaps unanticipated problems.

Prior to its amendment section 389 read in part: "when a complete determination of the controversy can not be had without the presence of other parties, the court must then order them to be brought in ...." Although the section spoke in mandatory terms and made no distinction between necessary and indispensable

${ }^{1}$ Cat. Code Crv. Proc. \$ 389: "A person is an indispensable party to an action if his absence will prevent the court from rendering any effective judgment between the parties or would seriously prejudice any party before the court or if his interest would be inequitably affected or jeopardized by a judgment rendered between the parties.

"A person who is not an indispensable party but whose joinder would enable the court to determine additional causes of action arising out of the transaction or occurrence involved in the action is a conditionally necessary party.

"When it appears that an indispensable party has not been joined, the court shall order the party asserting the cause of action to which he is indispensable to bring him in. If he is not then brought in, the court shall dismiss without prejudice all causes of action as to which such party is indispensable and may, in addition, dismiss without prejudice any cause of action asserted by a party whose failure to comply with the court's order is wilful or neghigent.

"When it appears that a conditionally necessary party has not been joined, the court shall order the party asserting the cause of action to which he is conditionally necessary to bring him in if he is subject to the jurisdiction of the court, if he can be hrought in without undue delay, and if his joinder will not cause undue complexity or delay in the proceedings. If he is not then brought in, the court may dismiss without prejudice any cause of action asserted by a party whose failure to comply with the court's order is wilful or negligent.

"Whenever a court makes an order that a person be brought into an action, the court may order annended or supplemental pleadings or a cross-complaint filed and summons thereon issued and served.

"If, after additional conditionally necessary parties have been brought in pursuant to this section, the court finds that the trial will be unduly complicated or delayed because of the number of parties or causes of action involved, the court may order separate trials as to such parties or make such other order as may he just."

Prior to the amendinent, section 389 provided:

"The court may determine any controversy between parties before it, when it can be done without prejudice to the rights of others, or by saving their rights; but when a complete determination of the controversy can not be had without the presence of other parties, the court must then order them to be brought in, and to that end may order amended and supplemental pleadings, or a cross-complaint to be filed, and summons thereon to be issued and served. And when, in an action for the recovery of real or personal property, or to determine conflicting claims thereto, a person, not a party to the action, but having an interest in the subject thereof, makes application to the court to be made a party, it may order bim to be brought in, by the proper amendinent."

The last sentence of the section as it read prior to the recent amendunent is now contained im CaL. Code Civ. Proc. \$389.5.

2 CAL. CODE Crv. Proc. $\$ 442$ : "Whenever the defendant seeks affirmative relief against any [party] person, whether or not a party to the original action, relating to or depending upon the contract, transaction, matter, happening or accident upon which the action is brought or affecting the property to which the action relates, he may, in addition to his answer, file at the same time, or by permission of the court subsequently, a cross-complaint. The cross- 
parties, ${ }^{3}$ it was interpreted by the courts to require the joinder only of an indispensable party and inerely to permit, in the discretion of the court, the joinder of a necessary party. 4

In its report, the California Law Revision Commission stated that section 389 had been subjected to varied interpretations by the courts, and that the purpose of the amendment was to provide explicitly that indispensable parties must be joined and that necessary parties nnay be joined if the court finds it advisable to do so. ${ }^{5}$ In view of the fact that there had been little question as to the meaning of section 389 since the decision in Bank of California v. Superior Court, ${ }^{6}$ the need for clarification of the section is questionable. Moreover, because of an unfortunate choice of language, it is possible that the amendment has confused, rather than clarified, the California practice with respect to joinder of parties.

In the past the judicial definition of an indispensable party was phrased in terms of the effect of lis absence upon his rights, as well as the futility of a judgment without his presence. ${ }^{7}$ In defining indispensable parties, section 389 now speaks in terms of prejudicing the rights of the parties before the court, as well as those of the absent party.$^{8}$ Further, the section states that the absent party is indispensable if his interests would be inequitably affected by a judgment without his presence. ${ }^{9}$ Previously, the test had been whether the judgment would directly affect the absent party's interest in the subject matter of the controversy before the court. In construing section 389 the courts will be faced with the question of whether these differences in phraseology alter the existing test of a party's classification.

Section 389 states that a necessary party is one "whose joinder would enable the court to determine additional causes of action" arising out of the subject matter of the controversy before the court. The former verbalization of a necessary

complaint must be served upon the parties affected thereby, and such parties may demur or answer thereto, or file a notice of motion to strike the whole or any part thereof, as to the original complaint. If any of the parties affected by the cross-complaint have not appeared in the action, a summons upon the cross-complaint must be issued and served upon them in the same manner as upon the commencement of an original action." (The word "party" in brackets was deleted by the 1957 amendment and the italicized portion added thereby.)

3 Parties are generally classified into three groups: (1) proper parties, who have no interest in the controversy between the immediate litigants, but have such an interest in the subject matter as may be conveniently settled in the suit, and thereby prevent further litigation; (2) necessary parties, who have an interest in the controversy, but whose interests are separable from those of the parties before the court, and will not be directly affected by a judgment between those parties; (3) indispensable parties, who not only have an interest in the subject matter of the controversy, but an interest of such a nature that a final judgment cannot be made without directly affecting their interests. See, e.g., Bank of California v. Superior Court, 16 Cal.2d 516, 106 P.2d 879 (1940).

4 Simmons v. California Institute of Technology, 34 Cal. 2d 264, 209 P.2d 581 (1949); Bank of California v. Superior Court, 16 Cal. 2d 516, 106 P.2d 879 (1940).

- Cal. Law Revision Comar., Recomarendation and Study Relating to Bringing New Parties Into Civm Actions 5 (1957).

616 Cal. 2d 516, 106 P.2d 879 (1940).

7 Bowles v. Superior Court, 44 Cal. 2d 574, 283 P.2d 704 (1955) ; Hartman Ranch Co. v. Associated Oil Co., 10 Cal.2d 232, 73 P.2d 1163 (1937); Wamer v. Pacific Tel. \& Tel. Co., 121 Cal. App. 2d 497, 263 P.2d 465 (1953); Baines v. Zuieback, 84 Cal. App. 2d 483, 191 P.2d 67 (1948); McKelvey v. Rodriguez, 57 Cal. App. 2d 214, 134 P.2d 870 (1943).

8 The writer has been able to find only one authority using such language: STORY, EQUITY Pleadings \& 77 (5th ed. 1852).

"No authorities have been found which so use the word "inequitably" in describing indispensable parties. 
party was one whose absence would prevent a complete determination of the controversy between the parties already before the court. ${ }^{10}$ While this revised language may be interpreted by the courts as simply another way of stating the same test, there are situations where the joinder of a new party would enable the court to determine additional causes of action arising out of the subject matter of the controversy before the court, even though that person's joinder would not be necessary to permit a complete determination of the controversy between the parties already before the court. ${ }^{11}$ If this definition is given its literal meaning, the class of persons denominated necessary will be expanded to include many who formerly would have been merely proper parties.

From the foregoing discussion it is apparent that section 389 as anended is susceptible to being construed as laying down new tests for determining the status of a party as indispensable or necessary. ${ }^{12}$ It is subinitted, however, that it is a practical impossibility to formulate concrete tests for determining the status of the new party. Since the new phraseology used in section 389 apparently has not been used in any cases applying the section before its amendment, there is no guide as to the meaning of the new terms. Furthermore, the California Law Revision Commission indicated that its purpose in proposing the amendment was merely to clarify, not to alter, the existing definition of indispensable and necessary parties. It is therefore to be anticipated that the courts will ignore the unique phraseology of section 389 and will continue to apply the rules as developed in the Bank of California case, determining the status of the absent party according to the peculiar facts of eacl case rather than restricting themselves by attempting to formulate a test applicable to all situations.

10 Bowles v. Superior Court, 44 Cal. 2 d 574, 283 P.2d 704 (1955); Ambassador Petrolcum Co. v. Superior Court, 208 Cal. 667, 284 Pac. 445 (1930); Hahn v. Walter, 60 Cal.App. 2d 837, 141 P.2d 925 (1943). There are apparently no cases using the language now contained in section 389 .

11 An example is the second hypothetical case discussed in connection with section 442 . See text at note 24 infra.

12 Two other changes in section 389 bear discussion, but do not relate directly to the sub. ject of this article. In dealing with the sanctions for failure to secure the joinder of a party after having been ordered by the court to do so, section 389 states that "the court may dismiss without prejudice any cause of action asserted by a party whose failure to comply with the court's order is wilful or neghgent." Formerly the sanction for failure to comply with an order to secure the joinder of a new party was dismissal of the cause of action to which the absent party was indispensable or necessary, as the case may be, such dismissal being compulsory if the absent person was an indispensable party. Warner v. Pacific Tel. \& Tel. Co., 121 Cal. App. 2d 497, 263 P.2d 465 (1953) ; Loock v. Pioneer Title Insurance and Trust Co., 4 Cal. App. 2d 245, 40 P.2d 526 (1935). Also, section 389 states that the court shall order in a necessary party if certain conditions are met. Non-joinder of an indispensable party goes to the jurisdiction of the court, requiring dismissal of the action if such party is not joined, and objection to non-joinder of an imdispensable party is not waived by failure to assert it in the answer or demurrer. But failure to object to the non-joinder of a necessary party had heretofore caused a waiver. Bank of Cabifornia v. Superior Court, 16 Cal.2d 516, 106 P.2d 879 (1940); Smith v. Cucamonga Water Co., 160 Cal. 611, 117 Pac. 764 (1911). See also Car. Code Crv. Proc. § 434, which provides that the only objections not subject to waiver are lack of jurisdiction of the court and failure of the complaint to state a cause of action. The courts would probably be reluctant to give this portion of section 389 the interpretation that absence of a necessary party now goes to the jurisdiction of the court and has the same effect as non-joinder of an imdispensable party. This language will probably be given the interpretation that the court must order in the necessary party if, in its discretion, it is found to be expedient to do so, thus causing no change in the prior practice. However, the portions of the section dealing with sanctions for wilful or negligent non-compliance with a court order for jomder are explicit and probably will be given literal effect. 
Unlike the amendment to section 389 , however, the amendment to section 442 was designed to change the prior practice and thus raises many important problems. A brief history of the judicial interpretation of section 442 should prove helpful in determining the effect of the amendment.

Prior to the 1957 amendment, the leading case interpreting section $442^{13}$ was Alpers v. Bliss, decided in $1904 . .^{14}$ In that case defendant asserted against the plaintiff and a third party a claim that related to the property upon which plaintiff's action was based. The court held that this did not warrant a cross-complaint against the new party, stating that section 389 , not section 442 , provided the authority and established the conditions for bringing in a new party by crosscomplaint or otherwise. ${ }^{15}$

In 1907 the section was amended by the addition of "to the action" following "party." I6 It was held in Merchants' Trust Co. v. Bentel 17 that by this ainendment the Legislature intended to codify the earlier Alpers holding. In 1915, however, these words ("to the action") - were deleted from the section by an amendinent, seemingly overriding the earher case law and authorizing new parties to be brought in by cross-complaint. ${ }^{18}$ Despite this evidence of legislative intent to adopt a broader provision, the courts continued to construe and apply section 442 as they did before 1915. In so doing they often relied upon Reed $v$. Wing, ${ }^{19}$ a case decided at a time when the section contained the language deleted in 1915.

Consequently, it became thoroughly estabhished that a cross-complaint could not be asserted against a person who was not a party before the court. However, if the new party was an indispensable or necessary party to the controversies already before the court, ${ }^{20}$ a cross-complaint could be asserted against him after an order for his joinder was issued under section 389.

As recently amended section 442 reads in part: "whenever the defendant seeks affirmative relief against any person, whether or not a party to the original action ...." This amendment was intended to liberalize the former practice with regard to the assertion of cross-complaints against new parties. ${ }^{21}$ The extent and rami-

13 As originally enacted the section read substantially as it did prior to the 1957 amendment. CaI. CODE Axidrs. 1873-74, 301. The entire last sentence, requiring the issuance of summons and service upon those parties who had not appeared in the action was added in 1909. Cal. Stat. 1909 , c. 629 , § 1 .

14145 Cal. 565, 79 Pac. 171 (1904).

15 "The provision of section 442 of the Code of Civil Procedure, giving to a defendant who may seek affirmative relief 'against any party' the right to file a cross-complaint at the same time that he files his answer, is limited to cases in which he seeks affirmative relief against a 'party' to the action. This section does not give him a right to file a cross-complaint for affirmative relief against one who is not already a party to the action, or to bring new or additional parties into the action by including them in his cross-complaint as defendants thereto. He cannot bring a new party into the action without an order of court therefor." $145 \mathrm{Cal}$. at 570, 79 Pac. at 173.

16 Cal. Stat. 1907, c. $372, \S 6$.

1710 Cal. App. 75, 101 Pac. 31 (1909).

18 Cal. Stat. 1915, c. 141, §1.

19168 Cal. 706, 144 Pac. 964 (1914).

20 Alpers v. Bliss, $145 \mathrm{Cal}$. 565, $79 \mathrm{Pac} .171$ (1904) held that the controversy before the court referred to in section 389 included not only that raised in the complaint, but also that of a cross-complaint asserted against a party already before the court. Thus a new party could be joined under section 389 if he were necessary or indispensable to a controversy raised either in the complaint or in a cross-complaint asserted against a party before the court.

21 See Cal. Law Revision Conar., Reconminndation and Study Reiating to Bringtavg New Parties Into Civtr Actions 5 (1957). 
fications of the intended liberalization may be examined by application of the section to several hypothetical factual situations and comparison of the new standards with those of the Federal Rules of Civil Procedure.22

(1) Cars driven by $A, B$ and $C$ are involved in a collision. Driver $A$ sues driver $B$, and $B$ wishes to assert a cross-complaint against both drivers $A$ and $C$. Prior to the amendment to section $442, B$ could have brought such a cross-complaint against $A$, the plaintiff, but a cross-complaint could not lave been asserted against $C$ because lie was not a necessary party to the cause stated either in the complaint or in $B$ 's cross-complaint against $A$. Nor could a counterclaim be asserted against $C$ under the Federal Rules of Civil Procedure. Under Rule 13(h), $C$ could not be unade a co-defendant to a counterclainn against $A$ unless $C$ were a necessary party to such a counterclaim. ${ }^{23}$

(2) Cars driven by $A, B$ and $C$ are involved in a collision. $X$, a passenger in $A$ 's car, sues $B$, and $B$ desires to assert a cross-complaint against drivers $A$ and $C$. A cross-complaint could not have been asserted against either $A$ or $C$ prior to the amendment to section 442 , because neither were necessary parties to the claim asserted by $X$ against $B$. Neither $A$ nor $C$ could be brought in under Federal Rule 13 (11), because there is no counterclaim against an opposing party to which they could be made co-defendants, even if they would have been necessary parties to sucl a counterclaim. ${ }^{24}$

It is to be noted that this second situation is more extreme than the first. In the first case, the cross-complaint against $A$ is clearly permissable, and the question is whether $C$ can be made a co-defendant thereto without an order of court under section 389. In the second case, there is no proper cross-complaint against a party; thus the question is whether a cross-complaint may be asserted solely against a new party. This latter procedure is not permitted even under the liberal provisions of the Federal Rules of Civil Procedure, except in the case of impleader under Rule 14.

(3) $A$, a consumer, sues $B$, a retailer, alleging that $B$ is liable for injuries caused by an exploding bottle purchased from $B$. $B$ wishes to assert a cross-complaint against $C$, the manufacturer, alleging that $C$ is or may be liable to $B$ for all or part of the claim asserted against $B$ by $A$. This action-over against $C$ would not have been allowed prior to the amendment to section 442 , because $C$ was not a necessary party to $A$ 's action against $B$. However, impleader in a situation such as this is allowed under Rule 14.

Not only are all the cross-claims described in the above situations permissible

22 A comparison with the Federal Rules of Civil Procedure seems appropriate not only because they are generally considered to be the model for liberal procedural rules, but also because the California Law Revision Commission had the Federal Rules in mind when it proposed the amendment to section 442. See Cal. Law Revision Comm'N, Recommendation and Studx Relating to Bringing New Parties Into Civil Actions 5 (1957).

${ }^{23}$ Fed. R. Crv. P. 13(h): "When the presence of parties other than those to the original action is required for the granting of complete relief in the determination of a counterclaim or cross-claim, the court shall order them to be brought in as defendants as provided in these rules, if jurisdiction of them can be obtained and their joinder will not deprive the court of jurisdiction of the action." FED. R. Crv. P. 19(b): "When persons who are not indispensable, but who ought to be parties if complete rehef is to be accorded between those already parties, have not been made parties and are subject to the jurisdiction of the court as to both service of process and venue and can be made parties without depriving the court of jurisdiction of tho parties before it, the court shall order them summoned to appear in the action ....."

24 Rule 13 (b) permits counterclaims only against an opposing party and Rule 13 (g) permits cross-claims only against a co-party. Rule 13 (h) permits the bringing in of a new party if he is a necessary party to a counterclaim or cross-claim already properly asserted. 
under the apparent meaning of section 442 as amended, ${ }^{25}$ but there is an indication that such was the objective of the California Law Revision Commission in proposing the amendment. ${ }^{26}$ In its report, the commission asserts that a crosscomplainant should have the same freedom in selecting cross-defendants as a plaintiff has in naming defendants, subject only to the restriction contained in section 442 concerning the subject matter relationship between the coinplaint and the cross-complaint. ${ }^{27}$ The plain meaning of the section, bolstered by the avowed purpose of the Law Revision Commission, probably will be given effect and all the cross-claims described above will be permitted under section 442 , without the necessity of first securing an order for the joinder of the new party under section 389.

However, a prediction that section 442 will be interpreted to permit a crosscomplaint against any new party if the subject unatter relationship requirement is met raises additional problems. Unlike Federal Rule 14, section 442 is silent as to the rights of the new party against whom a cross-complaint may be asserted. In the case of a third party being impleaded, Rule 14 provides that the third-party defendant may assert counterclaims against the third-party plaintiff and crossclaims against other third-party defendants in accordance with Rule 13. He may also assert against the original plaintiff any claim related to the subject matter underlying the original complaint, and may himself implead new parties who are or may be liable to him for the claim asserted against him. Rule 14 also provides that the original plaintiff may assert against the third-party defendant any claim related to the subject matter of the original complaint, and that if a counterclaim is asserted against a plaintiff, he may implead new parties, under circumstances which would permit a defendant to do so.

It is submitted that the new party against whom a cross-complaint is asserted should be entitled to the privileges of any other party to the action. Since section 442 is silent as to the determination of these questions, the California courts could well adopt the practice under Rule 14 with respect to the rights of the third person upon his being made a party. The provisions of Rule 14 deal only with the rights of a third party who has been inpleaded, but the same principles could be applied to a new party against whom any type of cross-claim is asserted. Some cases deal-

25 The action-over claim discussed in example three would probably be held to be one for affirmative relief within the ineaning of section 442 , in view of the fact that claims for liabilityover between co-defendants have been allowed under section 442 prior to its amendment. Television Arts Productions, Inc. v. Jerry Fairbanks, Inc., 134 Cal. App. 2d 293, 285 P.2d 695 (1955); County of Humboldt v. Kay, 57 Cal. App. 2d 115, 134 P.2d 501 (1943).

20 Car. Law Revision Comar'n., Recommendation and Study Retating to Bringtng New Parties Into Civil Actions 5 (1957). It is possible that the Law Revision Commission did not intend to authorize third-party practice as described in the third hypothetical. A study relating to the amendment to $\S 442$ was conducted on behalf of the Commission by Prof. Stanley Howell of the School of Law, University of Southern California, who recommended that no action be taken at the present time with respect to third-party practice. The failure of the Commission to mention this recommendation in its report is probably an indication that it did not have third-party practice in mind in proposing the amendment.

27 "... In this way piecemeal litigation will be avoided and the time of the court, counsel, parties, and witnesses will be conserved. The counmission recommends, therefore, that Code of Civil Procedure Section 442 be amended to provide expressly that the defendant may name as cross-defendants persons other than the parties to the original action. If through this procedure so many additional parties are brought in that the proceedimg becomes unwieldly, the court has the power under Code of Civil Procedure Section 1048 to order a severance in the interest of justice." Id. at 5 . 
ing with section 389 prior to its amendment indicate that a party who is joined under that section has all the rights of an original defendant, ${ }^{28}$ and this procedure would be consistent with the terms of section 442, which speaks of the rights of "the defendant."

It is readily apparent that if a defendant may assert against any new party a cross-claim which is related to the plaintiff's claim, the once simple action between a plaintiff and a defendant can become highly complex. This, together with the ability of the new party, who need not be necessary to the determination of the plaintiff's claim, to assert counterclaims, cross-claims, and third-party claims, can create a situation in which there are many issues which do not bear directly upon all the parties to the action. Such a result would seem to violate the principle that the plaintiff may select the parties with whom he desires to bitigate his claim. ${ }^{20}$ But it is in harmony with the policy of determining in one action as many related claims as possible in an effort to prevent multiple litigation..$^{30}$ This problem of complexity applies not only to section 442 , but also to section 389 , particularly if the amendment to the latter section is interpreted to expand the class of persons who may be joined thereunder. It was apparently with this in mind that the Legislature included the last sentence in section 389 , providing that the court inay order separate trials if it finds that the trial will be unduly complicated or delayed because of the number of parties or causes of action involved after new parties have been joined. Furthermore, section 1048 provides for severance of the various causes of action in the discretion of the trial court. ${ }^{31}$ Although section 442 seems to be a radical departure even from the liberal provisions of the Federal Rules of Civil Procedure, the courts could, if they deemed it advisable, practically negate the effect of the amendment to that section through a vigorous use of section 1048. Previously, a cross-complaint could not be asserted against a new party unless he was jomed first under section 389, and the court was invested with discretion to deny joinder of all but indispensable parties. Section 442 now seems to give the defendant the right to assert a cross-complaint against any new party, but the court may, in its discretion, order a separate trial, under section 1048, of the claim agamst the new party if he is not an indispensable party. ${ }^{32}$ In the final analysis, therefore, it is still within the discretion of the court to determine if new parties should be brought into the action, by cross-complaint or otherwise.

Richard A. Wilson*

28 See, e.g., Van Loben Sels v. Bunnell, 131 Cal. 489, 63 Pac. 773 (1901).

29 Clarg, Code Pleading \$ 64 (2d ed. 1947).

30 Ibid.

31 Cal. Code Crv. Proc. $\S 1048:$ "An action may be severed and actions may be consolidated, in the discretion of the court, whenever it can be done without prejudice to a substantial right."

32 The limitation in section 1048 prohibiting prejudice to a substantial right would seem to preclude severance of the claim against the new person if he were an indispensable party. Most of the cases citing section 1048 are concerned with consolidation, rather than severance. On severance, see Howe v. Key System Transit Co., 198 Cal. 525, 246 Pac. 39 (1926). With regard to severance under the Federal Rules, see FED. R. CIv. P. 13(i), 42(b), 54(b).

* Member, Second-Year Class 